\title{
The Principal's Strategies in Forming Student Character of SMP Al-Azhar Medan
}

\author{
Candra Wijaya ${ }^{1}$, Ali Imran Sinaga ${ }^{2}$, Widia Harahap ${ }^{3}$ \\ ${ }^{1,2,3}$ Postgraduate Program of Islamic Education, Universitas Islam Negeri Sumatera Utara, Medan, Indonesia \\ widiaharahap26@gmail.com
}

\section{Abstract}

This study aims to reveals the principal leadership strategies in forming student character in Al-Azhar Middle School Medan. The approach used in this study is a descriptive analysis approach. According to Sumadi Suryabrata, a descriptive approach is a form of approach that is carried out using a systematic and accurate scribal (exposure or description) regarding the facts and characteristics of the population. This approach is used to describe and analyze the leadership strategy of the Al-Azhar Medan Middle School leadership.The research location is a place where researchers conduct research so that researchers get information in accordance with the themes discussed. This research was conducted at Jalan Pintu Air IV No. 214 Kwala Bekala, District: Medan Johor, Medan City, and North Sumatera. The result shows that the principal's leadership strategy in forming the character of students are exemplar, discipline, advice and assign tasks to teachers.

Keywords character, students, the principal; SMP Al-Azhar Medan

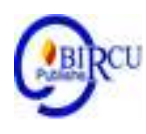

\section{Introduction}

One important issue in the administration of education in our country today is the formation of character, at various levels of education. Starting from primary, secondary, and higher education levels, including non-formal and informal education. This problem is highlighted by national education. The character to be built, according to the Minister of Education, is not only a character based on self-glory alone, but at the same time building the character of glory as a nation (Check the Minister of National Education's remarks on the commemoration of National Education Day 2011).

The problems of character education organizers that we can empirically know through various mass media such as newspapers and TV. For example, violence in the world of education by teachers against students and by fellow students, lecturers against students and between students, brawls between students and between students, drug abuse by elementary school students to students, corruption of school operational costs by principals and education officials. Students are quick to make decisions by suicide shortcut because they do not pass the UN or other personal problems, even the last event was a high school student killing his teacher. Sexual harassment by teachers to their students. All these character problems indicate the morale of students, educators, and education officials are still unable to implement the Ki Hajar Dewantara education paradigm, namely ing ngarso song tulodo, ing madyo mangun karso, tut wuri handayani (Suriansyah, 2015).

Character education aims to improve the quality of implementation and educational outcomes in schools that lead to the achievement of the formation of character and noble character of students as a whole, integrated, and balanced, according to graduate competency 
standards. Through character education students are expected to be able to independently improve and use their knowledge, study and internalize and personalize the values of character and noble character so that it is manifested in daily behavior (Siswanto, 2017).

Based on the Law of the Republic of Indonesia Number 20 of 2003 concerning the National Education System (Sisdiknas) Chapter II article 3 states that "National Education functions to develop capabilities and shape the character and civilization of a dignified nation in order to educate the nation's life aimed at developing the potential of learners to become people who have faith and are devoted to God Almighty, noble, healthy, knowledgeable, capable, creative, independent and become citizens of a democratic and responsible ". Along with the goals of national education, the current discussion on character education is the main focus to achieve the change of Indonesian people as a whole, who hold fast to religious and social values.

To realize character education properly in a school institution, it is necessary to have a management or school management. The intended management is how character education is planned, implemented, and controlled in activities in schools adequately (Syukur, 2011). Character is not formed instantly, but must be nurtured and trained seriously and professionally, so in learning there should be no gap between practice and the theory of character education for students to achieve perfect human beings (Maawiyah, 2015).

The leadership of a school principal is his ability to manage all available resources and influence, guide, direct all school members to be able to actively participate in, contribute to, and support all school programs and activities that are the mission and vision of the school (Alifiyah, 2019).

From the preliminary observations I made at SMP Al-Azhar Medan there was an effort by the headmaster to shape characters such as showing a model attitude for teachers, students, and educators at the school. The headmaster, who always arrives on time early in the morning to school, welcomes and checks on the completeness of the student's attributes. In addition, the principal also always evaluates students, teachers in teaching and learning activities and others through the custom of reading the Koran, the Tahfiz Alquran program will start learning from the beginning, reading Asmaul Husna, shaking hands with the teacher, praying duha and Friday prayers for male students male and female students, reading of student pledges at every flag ceremony, and having an extracurricular program. In addition, the use of English in the school environment every morning when the homeroom teacher from each class gives direction and instructions to students.

Based on this background, it illustrates the importance of developing the character of students in schools so that they can instill the character values that have been applied by the school in themselves so that they have a good personality that will be applied in their neighborhood or wherever he is. Of course, the formation of student character in this school can be carried out well with the existence of a principal's leadership strategy in shaping the character of students at school. Therefore, the authors are interested in conducting research on "The Principal Leadership Strategies in Forming Student Character in Al-Azhar Middle School Medan.

\section{Review of Literatures}

\subsection{Principal Leadership}

Leadership is an important factor and determines the success or failure of an organization in achieving its goals. Leadership in Indonesian means about the leader; how to lead. Leadership basically means the ability to lead; the ability to determine correctly what 
needs to be done. The ability in question is the ability that must be possessed by the principal to achieve educational goals. The principal as an education leader has a very important role to help teachers and students. School principals are teachers who are given additional duties as leaders in schools. The principal's position is a very strategic position, because it is one of the most determining factors in success in an education unit.

According to Gibson, leadership is the ability to influence others, which is done through interpersonal relationships and communication processes to achieve goals (Gibson, 1998). Newstrom and Davis argue that leadership is a process of organizing and helping others to work properly to achieve goals (Daviz and Newstrom, 1985). Whereas Stogdill believes that leadership is also a process of influencing group activities, with a view to achieving goals and work performance (Gibson, 1998).

Leadership becomes an integral part of human life. The main task on earth is as a leader. The task of leadership has also been assigned to humans since time immemorial ('azali) before humans were created. This is illustrated when God tells angels about the purpose and purpose of man being created, as stated in the QS. Al-Baqarah (2): 30 which states:

Meaning: Remember when your Lord said to the Angels: I want to make a caliph on earth ". They say: "Why do you want to make (the caliph) on earth a person who will cause damage to him and shed blood, even though we always glorify by praising you and purifying you? Allah says: "Verily, I know that which you do not know."

\subsection{Character Building}

The term character is also derived from the Greek word, charassein which means to carve into a pattern. According to Al-Ghazali in Megawangi, character is the behavior of someone who comes from a good heart. The character is not automatically possessed by humans, but requires a long process through education (Megawangi, 2004). While Ibnu Maskawih explained that morality is a state of the soul that pushes towards doing actions without thinking (longer) (Mahjuddin).

Wynne in Mulyasa explained that the character came from Greek which means "to mark" (mark) and focused there is how to apply the values of goodness in real actions or everyday behavior. Therefore, someone who behaves dishonestly, cheats, is cruel and greedy is said to have bad character, while those who behave well, are honest, and helpful are said to have a noble character (Mulyasa, 2008).

In the national policy it was emphasized, among others, that the building of the nation's character was a basic necessity in the process of nation and state. Since the beginning of independence, the Indonesian people have been determined to make national character development an important ingredient and not be separated from national development.

\subsection{Urgency of Students Learning Character Education}

In the world of education, deviant behavior among youth-students is increasing. For example, many of them are caught in drugs, promiscuity, brawl and thuggery. In addition, since the national examination policy is applied as a graduation standard, cheating behavior when exams have been conducted in groups by teachers, students and related parties. Likewise, the abuse and irregularities in the use of the education budget at the education unit level becomes news that adorns the media at any time.

The phenomenon of multidimensional crisis and the weakness of religious and citizenship education indicates that strengthening character education is absolutely necessary 
so that the next generation of the nation's future leadership can be saved from moral damage and multidimensional crises.

Character education is very important. The formation of character will determine how the person lives life. There are positive and negative characters. Planting positive characters is very necessary. It starts when a child is young and must be taught to have a positive character. This is useful as a capital for the child to live a life in the future. Children must have strong character, be brave and not give up easily.

\subsection{Application of Character Education in Schools}

Based on the functions and objectives of national education, it is clear that education at every level must be carried out systematically in order to achieve these goals. This relates to the formation of students' character so that they are able to compete, be ethical, moral, polite and interact with the community.

Based on research at Harvard University, it turns out that a person's success is not determined solely by knowledge and technical ability (hard skills) or intellectual intelligence, but rather by the ability to manage themselves and others (soft skills) or emotional and spiritual intelligence. This study revealed, success is only determined about 20 percent by hard skills and the remaining 80 percent by soft skills. Even the most successful people in the world can succeed because they are supported more by soft skills than hard skills. This suggests that the quality of character education of students is very important to be improved.

Apart from the various deficiencies in the practice of education in Indonesia, when viewed from the national education standards that serve as a reference for curriculum development, and the implementation of learning and assessment in schools, the actual educational objectives can be achieved well. Character development is also included in the material that must be taught and mastered and realized by students in daily life. The problem is, character education in schools so far has only touched the level of recognition of norms or values, and not at the level of internalization and concrete actions in daily life (http://akhmadsudrajat. wordpress.com/2010/09/15/konsep-pendidikan-karakter/).

\section{Research Method}

The approach used in this study is a descriptive analysis approach. According to Sumadi Suryabrata, a descriptive approach is a form of approach that is carried out using a systematic and accurate scribal (exposure or description) regarding the facts and characteristics of the population (Soejono, 1999). This approach is used to describe and analyze the leadership strategy of the Al-Azhar Medan Middle School leadership.

The research location is a place where researchers conduct research so that researchers get information in accordance with the themes discussed. This research was conducted at Jalan Pintu Air IV No. 214 Kwala Bekala, District: Medan Johor, Medan City, North Sumatera.

\section{Discussion}

\subsection{The Principal's Strategies in Forming Student Character of SMP Al-Azhar Medan}

The principal of SMP Al-Azhar Medan has many duties and responsibilities, such as planning programs that will be carried out, coaching staff teachers, other educators and students, making budget funds, chairing meetings, conducting good collaborations with other schools and surrounding communities, make annual reports and others. In addition, the principal also has a duty to improve the quality of students, especially for the formation of 
student character. Not only improving quality academically. This is in accordance with the mission and goals of SMP Al-Azhar Medan, namely: Carry out effective learning and guidance so that each student develops optimally in accordance with his potential, fosters a spirit of excellence intensively for school members in their work, fosters an appreciation of religious teachings embraced, fostering the nation's culture so that it becomes a source of wisdom in acting, and implementing greening and maintaining the environment so that the environment is beautiful and clean (Dokumentation of SMP Al-Azhar Medan).

From this mission, Syaiful Anshari, as the principal of SMP Al-Azhar Medan, developed strategies to improve student character. The forms of strategies made by the Principal of SMP Al-Azhar Medan are as follows:

\section{a. Modeling}

The example of the principal is very big influence on the course of the formation of character in the school because the principal as the leader who determines the peak of the success of the process of character formation in schools.

Based on interviews conducted by researchers to The principal of SMP Al-Azhar Medan about the principal's strategy in character building can be explained as follows:

"The first thing to do is that we have to be able to set an example for all teachers, students and stakeholders in this school. For example me and the teachers and pickets must arrive earlier than the students. Activities that should be exemplified directly by me and the teachers here are present just before 07.00 WIB in the morning, greeting and greeting others if they meet and meet saying politely and cleanly in appearance and so on " (Interview with Mr. Syaiful Anshari, M.Pd)

This opinion was also supported by the statement of the School Representative for The Principal's Strategies in forming student character of SMP Al-Azhar Medan can be explained as follows:

"The headmaster shows a good example for teachers, students and educators, as well as other parties in this school. He always arrives earlier than the teachers and students at this school. Welcoming students with friendly greetings. Establish good communication with the teachers here" (Interview with Mr. Abdul Hamidran Rangkuti, M.Pd)

This opinion was also supported by the statement of the Deputy School Student for Student Research, he revealed:

"The example begins with ourselves, including the principal, all teachers must do good things at school. As I see it, the principal is always disciplined and neat in appearance. The principal of SMP Al-Azhar Medan always comes in the morning before $07.00 \mathrm{WIB}$ to welcome students, plays a role in monitoring student neatness, personal hygiene with the teachers, and picket. Students will emulate if the principal and all teachers consistently show positive things to shape the character of students". (Interview with Mr. Ikhsanul Hidayat, S.Pd).

This opinion was also supported by the statement of the Islamic Teachers who also served as Coordinators of Islamic Religion to find out the strategies for forming students' character in SMP Al-Azhar Medan. He explained as follows:

"Small and simple behaviors such as courtesy when teaching in the classroom or outside the classroom, throwing trash in its place, coming on time, being honest and so on can be an example for students. Because of these small and simple things if always done by the teacher, then indirectly students will certainly imitate it" (Interview with Mr. Ali Sukri Harahap, M.Th.I).

Then, the researcher also interviewed the Citizenship Education teacher. He revealed: 
"Students are easily motivated by the good behavior displayed by the school principal and teachers. The teacher must say politely, understand student background. When the teaching and learning process takes place in the classroom, the teacher can give a good example in accordance with what he explained so that it can inspire students to enthusiasm in learning" (Interview with Ms. Husni, S.Pd).

After the researcher conducted an interview with The principal of SMP Al-Azhar Medan, the Representative of the Curriculum Field School, the Representative of the School of Student Affairs, the Religious Teacher, and the Citizenship Teacher, the researchers then made observations. Observations were carried out to observe the strategy carried out by The principal of SMP Al-Azhar Medan to shape the character of students in the school. Observations made in the school environment. From the results of observations made by researchers, that The principal of SMP Al-Azhar Medan in shaping the character of students by presenting himself first as an example at the school. Appearing disciplined and neat in appearance, he also arrived early in the morning before the teachers and students arrived. Take part in welcoming students at school well, smiling, greeting, greeting and checking the cleanliness and neatness of students in dressing.

Based on the interviews and observations above, it can be illustrated that the example is something related to the words, actions, attitudes, and behavior of someone who can be imitated or emulated by people. Exemplary should be used as one of the principal's strategies in shaping student character because exemplary is in accordance with the values of goodness and truth. Someone who has an example that will behave properly wherever located.

\section{b. Discipline}

Discipline is the attitude to obey the rules and regulations that have been set consciously to achieve the goals to be achieved. Rules that have educational value will shape the character of students to be good. Discipline must be instilled in students so that they become successful in the future.

Researchers interviewed The principal of SMP Al-Azhar Medan. He revealed:

"Discipline is very important, being the basic foundation of a person to be successful.

I, the teachers and staff always work together to shape the discipline of students here for example in terms of time discipline. I have to come to school earlier than the teachers, staff, and students at this school, and go home at the latest to make sure all learning activities are going well. To maintain student consistency in their discipline, a contact book and rules and rules for violation points and achievements of The principal of SMP Al-Azhar Medan are provided on each wall of the class are provided (Interview with Mr. Syaiful Anshari, M.Pd).

This opinion is also supported by the statement of the Deputy School Teacher of AlAzhar Medan Junior High School Curriculum about the principal's strategy in shaping the character of students can be explained as follows:

"The principal is always disciplined in terms of time. He always comes earlier than the teachers, staff, and students in this school. Always participating in welcoming students in the morning, when meetings are also present in the room before the teachers come".

This opinion was also supported by the statement of the Deputy School Student Affairs, he revealed:

"The enforcement of discipline must always be educated in students through the processes that have been planned in the student code of conduct. I always coordinate with the school principal, teachers, and staff in the SMP Al-Azhar Medan (Interview with Mr. Ikhsanul Hidayat, S.Pd). 
This opinion was also supported by the statement of the Teachers of Religion as well as who served as Coordinator of Islamic Religion to find out the principal's strategy in shaping the character of students at SMP Al-Azhar Medan. He explained as follows:

"I, the other teachers and school fathers always pay attention to the discipline of students in this school. The headmaster always comes earlier than me, the other teachers, and the staff at this school. I also have to arrive on time too, so that the students we expect discipline also come on time" (Interview with Mr. Ali Sukri Harahap, M.Th.I).

Then, the researcher also interviewed the Citizenship Education teacher. He revealed:

"Starting with ourselves, that discipline will be formed. If we want our students to be disciplined, the teachers are disciplined first. The headmaster always comes earlier than the teachers and students here, he is also friendly to students at this school, and always cares about the neatness and personal hygiene of students" (Interview with Ms. Husni, S.Pd)

Based on the interviews and observations above, it can be understood that discipline is very necessary in this case in the activities of forming students' characters. Discipline is the main requirement for success. Therefore, students are formed with discipline so that they become individuals who are identical with excellence, as the strategy that has been shown by The principal of SMP Al-Azhar Medan is to come earlier to school compared to teachers, staff, and students in this school, the aim is to train SMP Al-Azhar Medan students to have time discipline, so that they do not spend time on things that are of no use, but use the best time for positive things that support their success in learning especially has so that SMP AlAzhar students have good character.

\section{c. Advice}

In addition to giving exemplary and discipline to students of SMP Al-Azhar Medan, The principal of SMP Al-Azhar Medan also always reminds students that they behave well in school and do not violate school rules and regulations with advice. Because advice deals with good things and encourages others to do good.

Researchers interviewed The principal of SMP Al-Azhar Medan. He revealed:

"Students should always be reminded that they always behave well in this school, without advice, the formation of student character has not been formed optimally, because we as humans are not free from mistakes, especially what we will develop are students in adolescence who sometimes they are still easily influenced by their friend's bad behavior. For this reason, we must always convey advice every day to students as a strategy to form good character in students" (Interview with Mr. Syaiful Anshari, M.Pd).

This opinion is also supported by the statement of the School Representative for SMP Al-Azhar Medan Curriculum about the principal's strategy in forming the character of students can be explained as follows:

"The advice is very important for us to convey to students, because with good advice students will easily accept the calls of their teachers to behave well, so that he is motivated to learn. In my opinion, The principal of SMP Al-Azhar Medan always advises students to obey school rules. In each ceremony he always motivates students to be disciplined, diligent in worship, and have high motivation in learning" (Interview with Mr. Abdul Hamidran Rangkuti, M.Pd).

This opinion is also supported by the statement of the Deputy School Student in SMP Al-Azhar Medan about the principal's strategy in forming the character of students can be explained as follows: 
"Forming good character in students can be pursued by always reminding them of the school rules and regulations. The goal is that overall students are able to understand the rules of discipline and will not break them" (Interview with Mr. Ikhsanul Hidayat, S.Pd).

Based on the interviews and observations above, it can be illustrated that in order to shape the character of SMP Al-Azhar Medan students, The principal of SMP Al-Azhar Medan always reminds students that they behave well in school and do not violate school rules and regulations and behave polite to others. In this case he has positioned his role as a leader who provides guidance, direction, and advice so that students have good character and later become successful people.

Advice has a large enough influence to encourage children to behave morally, emotionally and socially with awareness that comes from within themselves. For this reason, principals and teachers must always strive to provide reinforcement and a good character base for students with good direction and guidance. The advice given will further touch the hearts of students to behave well and leave a meaningful impression so that students are able to carry out, practice and apply good character in their daily lives.

\section{d. Assign Tasks to Teachers}

The principal's leadership strategy in shaping the character of students can also be done by giving the task to the teacher to oversee all student activities in the school to support the process of character building for students.

Researchers interviewed The principal of SMP Al-Azhar Medan. He revealed:

"I leave the activities of student activities to picket teachers, religious teachers and homeroom teachers to always assist students in various activities at this school. Good collaboration is needed as an effort to succeed in the formation of students' character on an ongoing basis" (Interview with Bapak Syaiful Anshari, M.Pd).

Furthermore, researchers also interviewed PKS I of SMP Al-Azhar Medan Curriculum Field about the principal's strategy in forming the principal in forming the character can be explained as follows:

"The principal always motivates the teachers and staff at this school to always care about the activities of students. He invited the teachers to supervise everything that was done by students in the school, such as paying attention to the development of children's learning, memorizing the Surah of the Qur'an, cleanliness and neatness of students in dressing, and so on" (Interview with Mr. Ikhsanul Hidayat, S.Pd).

This opinion was also supported by the statement of the Representative School for SMP Al-Azhar Medan Students about the principal's strategy in shaping the character of students can be explained as follows:

"All parties in this school supervise the activities of students so that the formation of character is achieved optimally. Including supervising students so as not to violate rules and regulations in school. With this supervision, it is hoped that the teachers know to minimize the mistakes of students who like to violate school rules and regulations" (Interview with Mr. Ali Sukri Harahap, M.Th.I).

This opinion was also supported by the statement of Islamic Education Teachers who also served as Coordinator of Religion SMP Al-Azhar Medan as follows:

"Supervision is always carried out by the principal, teachers and staff at this school. Like accompanying students in prayer starting from inviting students to rush to the mosque, perform ablution correctly, until the prayer is finished. Always remind students who are less neat in dress, for example there are students who are less than perfect in wearing the hijab, as their hair is slightly visible. So the female teachers 
usually reminded her to wear the hijab properly, to supervise students when they were praying so that no one played around in prayer, and to process students who deliberately left their prayers with the specified sanctions" (Interview with Mr. Syaiful Anshari, M.Pd).

Furthermore, supervision conducted by the school principal, teachers and staff at the school on the activities of students at SMP Al-Azhar Medan will be evaluated once a month. Mr Syaiful said: "Usually we hold an evaluation meeting to monitor students who violate school rules and regulations with the teachers and staff at this Azhar High School."

After the researcher conducted an interview with The principal of SMP Al-Azhar Medan, Representative of the Curriculum Field School, the Representative of the School of Student Affairs, Religious Teachers, and Civics Teachers, the researchers then made observations. Observations were carried out to observe the strategy carried out by The principal of SMP Al-Azhar Medan to shape the character of students in the school. Observations made in the school environment. In carrying out student activities The principal of SMP Al-Azhar Medan always directs the teachers to accompany and supervise their students. For example, in the habituation activities of Dhuha prayer, Juhur prayer, and Asr the teacher accompanies students from ablution to prayer. In addition, each homeroom teacher is directed to examine the student's contact book and memorandum surah of the Quran (Observation on Monday, October 7, 2019).

Based on the interviews and observations above, it can be understood that to form the character of SMP Al-Azhar Medan students, The principal of SMP Al-Azhar Medan always motivate the teachers to accompany and supervise their students in all their activities in the school so that students do not violate school rules and regulations even he also participated in monitoring students who violate school rules and regulations and reminded students not to repeat their actions.

\section{Conclusion}

Based on some information obtained from interviews, observations and documentation of the findings about the focus of the principal's strategies in forming student character of SMP Al-Azhar Medan it can be concluded that the principal's leadership strategy in forming the character of students are:
a. exemplary
b. discipline
c. advice
d. assign tasks to teachers

\section{References}

Alifiyah, Ika, et al 2019. "Kepemimpinan Visioner Kepala Sekolah Dalam Mengembangkan Karakter Peserta Didik," dalam JAMP: Jurnal Adminitrasi dan Manajemen Pendidikan, vol. 2.

Astuti, R. W., Waluyo, H. J., and Rohmadi, M. 2019. Character Education Values in Animation Movie of Nussa and Rarra. Budapest International Research and Critics Institute-Journal (BIRCI-Journal) (2): 215-219.

Check the Minister of National Education's remarks at the commemoration of National Education Day 2011, Monday, May 2, 2011.

Dokumentation SMP Al-Azhar Medan. 
L Gibson, James, et . all, Organisasi Perilaku, Struktur, Proses, Alih bahasa : Djarkasih, Jakarta : Erlangga, 1988.

Maawiyah, Aisyah,. 2015.“Urgensi Pendidikan Karakter Dalam Pembelajaran,” dalam Itqan, vol. VI.

Mahjuddin, Akhlak Tasawuf, Padang: Kalam Mulia.

Megawangi, Ratna, Pendidikan Karakter Solusi yang Tepat untuk Membangun Bangsa, (Jakarta: BPMGAS, 2004.

Mulyasa, Management Pendidikan Karakter, Jakarta: PT Bumi Aksara, 2008.

Rahmanisa, A.,Suwandi, S. And Slamet Subiyantoro, S. 2018. Charactered Education in Learning Indonesian Language in the High School: Case Study in SMAN 1 Surakarta, Indonesia. Budapest International Research and Critics Institute-Journal (BIRCIJournal) (1): 29-39.

Siswanto, "Pendidikan Karakter Berbasis Nilai-Nilai Religius," dalam Tadris, vol. VIII.

Soejono dan Abdurrahman, Metodologi Penelitian Suatu Pemikiran Dan Penerapan, Jakarta: Rineka Cipta, 1999.

Suriansyah, Ahmad dan Aslamiah, "Strategi Kepemimpinan Kepala Sekolah, Guru, Orang Tua, Dan Masyarakat Dalam Membentuk Karakter Siswa," dalam Cakrawala Pendidikan, Juni 2015, Th. XXXIV, No. 2.

Syukur, Fatah, Manajemen Pendidikan Berbasis Madrasah, Semarang: Pustaka Rizki Putra, 2011.

Wahjosumidjo, Kepemimpinan Kepala Sekolah: Tinjauan Teoritik dan Permasalahannya, Jakarta: PT. Grafindo Persada, 2010.

Zarkasyi, Ritonga, A. A., and Nasution, W. N. 2020. Internalization of Islamic Religious Education Values in Scouting Extracurricular Activities in Forming Student Character in Public Middle School 2 Peunaron East Aceh. Budapest International Research and Critics Institute-Journal (BIRCI-Journal) (3): 838-848

Interview with Mr. Abdul Hamidran Rangkuti, M.Pd as Representative of the Curriculum Field School at SMP Al-Azhar Medan on Wednesday, October 9, 2019, at 11:00 WIB at the Office of the Curriculum Field School Representative at SMP Al-Azhar, Medan.

Interview with Mr. Ali Sukri Harahap, M.Th.I as a Teacher and Coordinator of Islamic Religion in SMP Al-Azhar Medan on Friday, October 11, 2019, at 08.30 WIB at SMP Al-Azhar Medan Teachers' Office in Medan.

Interview with Mr. Ikhsanul Hidayat, S.Pd as the Deputy School Student in SMP Al-Azhar Medan on Wednesday, October 9, 2019, at 10.20 WIB at SMP Al-Azhar Medan Teachers' Office in Medan.

Interview with Mr. Syaiful Anshari, M.Pd as the headmaster of SMP Al-Azhar Medan on Tuesday, October 8, 2019, at 09.00 WIB at SMP Al-Azhar Medan.

Interview with Ghisela Putri, grade IX student at SMP Al-Azhar Medan on Thursday, October 12, 2019, at 09.00 WIB in front of class IX Bilingual B, SMP Al-Azhar Medan.

Interview with Ms. Husni, S.Pd as the Study of Citizenship at SMP Al-Azhar Medan on Thursday, October 10, 2019, at 10.30 WIB at SMP Al-Azhar Medan. 